\title{
Comparison of the adverse renal effects of different types of NSAID based on COX inhibition in patients with headaches
}

\author{
Drita Yzeiri Havziu ${ }^{1 *}$, Biljana Gjorgjeska ${ }^{2}$, Visar Miftari $^{3}$, Edita Alili Idrizi ${ }^{1}$, \\ Gjylaj Alija $^{1}$, Arlinda Haxhiu ${ }^{1}$ \\ ${ }^{1}$ Faculty of Medical Sciences, State University of Tetovo, Street Ilinden bb 1200, \\ 1220 Tetovo, Republic of North Macedonia \\ ${ }^{2}$ Faculty of Medical Sciences, State University Goce Delcev, Krste Misirkov, 2000 Shtip, \\ Republic of North Macedonia \\ ${ }^{3}$ Clinic of Neurology, Clinical Hospital- November 29, 1220 Tetovo, \\ Republic of North Macedonia
}

Received: January 2020; Accepted: March 2020

\begin{abstract}
Migraine is a common headache disorder that causes significant disabilities. Non-selective cyclooxygenase (COX) inhibitors (piroxicam, ketoprofen and ibuprofen) are most widely-prescribed NSAIDs treatment of headaches. Celecoxib is another NSAID therapy that has been approved in the last several years, with different mechanisms of action. The purpose of the study is to follow the renal function and comparisons of nephrotoxicity of different types of NSAID based on COX inhibition, in patients with cefalea-migraine that has been treated for a long period.

Besides conventional markers of renal function (serum/urine creatinine determined by Jaffe's methods of enzymatic assay for urea in serum), we used nephelometry by $\beta 2$ microglobulin $(\beta 2 \mathrm{M})$ and photoelectric colorimetry for microalbuminuria in urine, to monitor glomerular and tubular functioning. Any history of kidney diseases was exclusion criteria to enter the study.

The results show that the greatest deviations are observed in $\beta 2 \mathrm{M}$ in terms of its increase in all patients treated with piroxicam and ketoprofen, in $91.7 \%$ of the patients treated with ibuprofen, and in $50 \%$ of patients treated with celecoxib. The most frequent decrease was shown in creatinine values in urine, in $50 \%$ of the patients of piroxicam-treated group, $66.7 \%$ of the group treated with ketoprofen and ibuprofen, and $75 \%$ of the patients treated with celecoxib.

Following the levels of specific biomarkers in urine we can recommend constant monitoring of renal functions during usage of different groups of NSAIDs and be careful while using analgesic-anti-inflammatory drugs.
\end{abstract}

Keywords: adverse renal effects, non-steroidal anti-inflammatory drugs, migraine

\section{Introduction}

Migraine is the most common cause of headache and contributes to severe neurological disorder with serious socioeconomic burden. Its prevalence ranges between
$12 \%$ and $20 \%$ in different countries worldwide, more common in women than in men. According to Lipton et al. (2001), Rozen et al. (1999) and Stewart et al. (1992), $80 \%$ of the patients report a family history. Despite introducing triptans, a new class of migraine-specific drugs more than a decade ago, with superior efficacy,

\footnotetext{
*drite.havziu@unite.edu.mk
} 
non-steroidal anti-inflammatory drugs (NSAIDs) remains among the most commonly used migraine attack therapies, suggested by the European Federation of Neurological Societies - EFNS (Evers et al., 2009). Some groups of treatments are available in pharmacies without a prescription and are usually much cheaper than triptans, which contributes to their abuse among patients suffering from migraine. According to Tulunay et al. (2000) their usage in treatment of migraine is followed by their analgesic, anti-inflammatory and antipyretic effects, including other pain etiologists, supported by indirect evidence that prostaglandins are involved in the pathophysiology of migraines

According to the results of the studies of Derry et al. (2014), Rothrock et al. (2011) and Quiralte et al. (2007), diclofenac has been shown to be one of the world's most widely prescribed NSAIDs as an inhibitor - both cyclooxygenase 1 (COX-1) and cyclooxygenase 2 (COX2 ) and presenting great efficacy in ranking the therapeutic options for migraine therapy with advantages over oral sumatriptan. Conventional NSAIDs are an nonselective inhibitors of both isoforms, unlike COX-2-specific NSAIDs, which are also effective in relieving the symptoms of migraine. New COX-2 inhibitors (coxibi) are highly effective and more rapidly absorbed by nonselective inhibitors, providing benefits in rapid mechanism of action for acute drug therapy and preventing the development of central sensitization, which reduces the likelihood of a successful outcome. Meloxicam is another selective COX-2 inhibitor that NSAIDs had approved in recent years (Furst et al., 1997). According to Sagar et al. (2011), the efficacy of a new oral liquid formula of celecoxib intended for the acute treatment of adults with episodic migraine.

Based on the selective COX inhibition in accordance to COX-1/COX-2 - IC50 coefficient NSAIDs are divided into:

- Selective COX-1 inhibitors such as aspirin with COX-1/COX-2 coefficient IC50 of 0.01 .

- Non-selective COX inhibitors (the drug equally inactivates the two cyclooxygenase isoforms): with COX-1/COX-2 - IC50 coefficient between 0.5 and 3 ;

- Relatively selective COX-2 inhibitors - are characterized by a lower inactivation of the COX-1 enzyme such as: meloxicam, nimesulide, diclofenac, with COX-1/COX-2 - IC50 coefficient between 10 and 20; Highly selective COX-2 inhibitors, a celecoxib prototype with COX-1/COX-2 - IC50 coefficients between 140 and 250, placebo-controlled COX-2 only, are known as coxibs and referred to as selective COX-2 inhibitors (Sylejman et al., 2007; Yzeri Havziu, 2014).

The main effect of conventional NSAIDs is the nonselective inhibition of both isoforms, unlike Coxibs, a class of non-steroidal anti-inflammatory drugs (NSAIDs) that perform selective inhibition only COX-2. According to Raz et al. (2002) and Parezela et al. (2001), the paradox is that most NSAIDs also block COX-1 and not only COX-2, which means that they block the synthesis of all prostaglandis, effecting the normal physiological renal function. Wilam et al. (2000) have confirmed that concomitant prostaglandin inhibition in the kidney can reduce renal blood flow and glomerular filtration rate (GFR). Thereby, promoting sodium and water retention, where renal hypoperfusion may result in acute kidney injury (AKI). This risk is present even when COX-2 selective NSAIDs are used. Up to $20 \%$ of patients who take nonselective NSAID and have more than one of these risk factors may manifest alterations in renal function (Raymond et al., 2006).

Many studies have suggested that COX-2-selective inhibitors cause less renal side effects, including decreased glomerular filtration rate (GFR), elevated serum creatinine $(\mathrm{CrS})$ and hypertension, comparing to nonselective NSAIDs (Silverstein et al, 2000; Whelton et al., 2000). On the other hand, other studies did not show significant differences in renal risk between COX-2 selective inhibitors and non-selective NSAIDs (Swan et al., 2000; Whelton et al., 2000).

According to the study of Weir et al. (2002), based on clinical trials on comparing renal changes between non-selective NSAIDs and coxibi, the results indicate only subtle changes in renal hemodynamics. They found that the renal effects of celecoxib are similar to non-selective NSAIDs. The highest incidence of AKI (Acute kidney injury) is reported during usage od Indomethacin in combination with ibuprofen and piroxicam (Griffin et al., 2000). Celecoxib, a selective COX-2 inhibitor, has a lower risk of developing AKI, compared to other non-selective NSAIDs (Schneider et al., 2006; Winkelmayer et al., 2008). According to Swan et al. (2006), diclofenac sodium, compared to meloxicam resulted in a higher degree of nephrotoxicity. So they suggested that diclofenac sodium can be replaced with meloxicam. The damaging effects of diclofenac sodium and meloxicam on kidney tissue in animals are well documented in the literature.

Many nephrologists report that NSAIDs have been classified into the second group, after nephrotoxicity and aminoglycosides as the cause of AKI (Schrier et al., 1984). More recent studies have summarized enumerated phases of nephrotoxicity caused by NSAID as following conditions: acute renal impairment, chronic renal impairment, interstitial nephritis, and subclinical nephrotoxicity. It is clear that all NSAID groups are associated with all forms of renal impairment, but however, if detected early, acute syndromes have a good prognosis, However, this assumption does not apply to chronic renal impairment (Clive et al., 1984; Ejaz et al., 2004; Yzeri Havziu, 2014).

Traditional laboratory analyzes for the detection of renal impairment, which includes creatinine, creatinine 
clearance, urea, electrolytes, are not only sensitive and specific, but they also do not allow early detection of renal impairment. That effects the adequate detection of differentiation between the various degrees of AKI and as such cannot be used as a signal for stopping therapy with drugs that exhibit strong nephrotoxicity (Liangos et al., 2007). In fact, until recently the rise in serum creatinine (CrS) was widely considered to be the "gold standard" for detecting AKI. It is now clear that $\mathrm{CrS}$ changes when $50 \%$ of renal function is lost. It is therefore very important, in addition to these parameters, to follow certain biomarkers, which were previously determined in vivo conditions on experimental animals and then used as modeling systems for the human organism (Prasad et al., 2005; Yzeri Havziu, 2014).

Recent literature data suggests the possibility of monitoring the bioindicator early detection of nephrotoxicity occurring during NSAIDs (Spasovski et al., 2007; Yzeri Havziu, 2014) proteins and albumin that can be of serum or urinary origin are used as biomarkers. Excretion of high molecular weight albumin and protein (> 80000) in urine indicates damage to glomeruli (Davis et al., 1994), and low molecular weight proteins and albumin: $32 \mathrm{M}$, indicates changes in the tubules.

There is relatively little data to compare the nephrototoxicity of different types of NSAIDs based on COX inhibition in patients with cephalea-migraines, treated in different periods times. The purpose of the study is to compares renal function based on COX inhibition and detect early nephrotoxicity using specific bioindicators.

\section{Materials and methods}

To accomplish the goal of this study we used urine and venous blood from randomly selected patients of Clinical Center-Neurology-Tetovo (Polog Region of R.N.M), with chronic headache--migraine, with normal renal function. The study included a total of 48 patients with an average age of $42.047 \pm 7.41$ years, with a range of 35-65 years with mean follow-up of up to $120 \pm 12.6$ months treated with different groups of NSAID: non selective COX inhibitors (piroxicam, ketoprofen and ibuprofen) and selective COX-2 inhibitors (celecoxib). The dose, treatment period, migraine episodes and drug usage frequency are displayed in Table 1.

Patients included in the examination were informed about the method of implementation and the purpose of the research before giving their written consent. They were also asked not to use any other medicines before taking the examinations. Patients with prior renal disease were excluded from the study. The examination was conducted according to the designed protocol, respecting the ethical principles of the Helsinki Declaration on Medical Research on People and Licenses from the Ethic Committee of the Faculty of Medical Sciences at the University "Goce Delcev" - Stip (WMA, 2000). The results represent the average value of the three measurements, made under identical conditions. In purpose of analysis sample was used $5 \mathrm{~mL}$ of blood, collected in special tubes, without anticoagulants. All materials for analysis are measured in the laboratories of Clinical Hospital in Tetovo.

To determine of creatinine and specific biomarkers ( $\beta 2 \mathrm{M}$ and microalbuminuria), the first morning urine was used. The samples were processed according to the protocol described by Yzeri Havziu et al. (2016) and subsequently used for further biochemical characterization.

For testing the creatinine serum/urine, we used the Jaffe method - during the reaction of the creatinine with the basic reagents (Flex reagent cartridge), a complex of red color is formed, which is followed by measuring the change of absorbance at a time interval of $510 \mathrm{~nm}$ (Dimension Rxl) (Yzeri Havziu et al., 2017).

Urea serum, the enzymatic-urea hydrolysis under the influence of the urease enzyme, the formed ammonia $\left(\mathrm{NH}_{3}\right)$ reacts with the catalytic effect of the GLDH (Flex Reagent Cartridge), $\alpha-K G$ (Flex Reagent Cartridge) and NADH (Flex Reagent Cartridge). As a result of the reaction, glutanamic acid and NAD are formed. The decrease in absorbance due to the reduced $\mathrm{NADH}$ oxidation is proportional to the release of the urea $\mathrm{NH}_{3}$, measured at a value of 340 and $383 \mathrm{~nm}$ (Dimension Rxl) (Yzeri Havziu, et al., 2017).

Table 1. Drugs, Dose, treatment period, migraine episodes and drug usage frequency

\begin{tabular}{|c|c|c|c|c|c|}
\hline Drugs & $\overline{\mathrm{N}}$ & $\begin{array}{c}\text { Dose } \\
\mathrm{Mg} \\
\text { (per day) }\end{array}$ & $\begin{array}{c}\text { Period of } \\
\text { Treatement } \\
\text { (per year) }\end{array}$ & $\begin{array}{c}\text { Migraine } \\
\text { Episodes } \\
\text { (days in month) }\end{array}$ & $\begin{array}{c}\text { Drug Usage } \\
\text { Frequency } \\
\text { (days in month) }\end{array}$ \\
\hline Piroxicam & 12 & 20 & $>5$ to 10 & $<15$ & $<15$ \\
\hline Ketoprofen & 12 & 100 & $>5$ to 10 & $<15$ & $<15$ \\
\hline Ibuprofen & 12 & 600 & 5 & $<15$ & $<15$ \\
\hline Celecoxib & 12 & 200 & 1 & $<15$ & $<15$ \\
\hline
\end{tabular}


Table 2. Comparison of the mean and median values of the analyzed parameters (BUN, CrS, CrU, NaS) of Piroxicam, Ketoprofen, Ibuprofen and Celecoxib.

\begin{tabular}{|c|c|c|c|c|c|c|}
\hline \multirow{3}{*}{$\begin{array}{l}\text { Biochemical } \\
\text { Parameters }\end{array}$} & \multirow{3}{*}{$\begin{array}{c}\text { median } \\
(25-75 \text { percentiles })\end{array}$} & \multicolumn{5}{|c|}{ p-level } \\
\hline & & & \multicolumn{4}{|c|}{ intergroup differences } \\
\hline & & & & Ketoprofen & Ibuprofen & Celecoxib \\
\hline \multirow[t]{4}{*}{ 1BUN } & $4.4(3.75-4.75)$ & $\mathrm{H}=20.79$ & Piroxicam & $\mathrm{ns}$ & ns & 0.0030 \\
\hline & $5.55(4.7-7.05)$ & $\mathrm{p}=0.0001 \mathrm{sig}$ & Ketoprofen & & 0.0450 & ns \\
\hline & $4.15(4.11-4.7)$ & & Ibuprofen & & & 0.0004 \\
\hline & $6.4(6.3-6.6)$ & & Celecoxib & & & \\
\hline \multirow[t]{4}{*}{$1 \mathrm{CrS}$} & $65.5(59.5-78.5)$ & $\mathrm{H}=6.42$ & Piroxicam & & & \\
\hline & $63(50.5-71)$ & $\mathrm{p}=0.0900 \mathrm{~ns}$ & Ketoprofen & & & \\
\hline & $68(61.5-83)$ & & Ibuprofen & & & \\
\hline & $82(74.5-82.5)$ & & Celecoxib & & & \\
\hline \multirow[t]{4}{*}{$1 \mathrm{CrU}$} & $13.25(8.8-17.7)$ & $\mathrm{H}=3.88$ & Piroxicam & & & \\
\hline & $8.8(6.6-15.5)$ & $\mathrm{p}=0.2700 \mathrm{~ns}$ & Ketoprofen & & & \\
\hline & $8.8(8.8-17.7)$ & & Ibuprofen & & & \\
\hline & $4.4(4.4-13.25)$ & & Celecoxib & & & \\
\hline \multirow[t]{4}{*}{$1 \mathrm{NaS}$} & $140(138.5-140.5)$ & $\mathrm{H}=9.38$ & Piroxicam & $\mathrm{ns}$ & $\mathrm{ns}$ & 0.0330 \\
\hline & $139.5(137.5-140.5)$ & $\mathrm{p}=0.02500 \mathrm{sig}$ & Ketoprofen & & ns & ns \\
\hline & $138(138-140.5)$ & & Ibuprofen & & & ns \\
\hline & $137(137-137.5)$ & & Celecoxib & & & \\
\hline
\end{tabular}

Serum electrolytes - Ion Selective Electrodes (ISE) determine the difference in the electrochemical potential between the glass or liquid membrane electrode (Flex Reagent Cartridges) and the reference electrode (Flex Reagent Cartridges) that is proportional to the concentration of electrolytes in the serum.

For the determination of urinary albumin, microalbuminuria, we used visual Reading urine tape test in Combilyzer 13 - a test is based on the "protein error" principle of the indicator, which is caused by the presence of albumin. Sulfanephthalein has a high sensitivity to albumin. The color fields correspond to following values: $10,30,80$ and $150 \mathrm{mg} / \mathrm{L}$ urinary albumin.

For $\beta 2 \mathrm{M}$ determination imunonephelometry by $\mathrm{BN}$ II/BN ProSpec ${ }^{\mathrm{R}}$ System was used.

\section{Statistical data processing}

Statistical data processing was performed in SPSS for Windows 23.0 statistical software.

Shapiro-Wilks tests, as well as skewness and kurtosis measures were used to test the normality of the data distribution

Nonparametric and parametric tests for independent samples (H Kruskal-Wallis test) and post - hoc (MannWhitney test), were used to compare the analyzed groups.
The data of interest are shown in tables and graphs. P values $<0.05$ were considered statistically significant

\section{Results and discussion}

Results of comparison of mean and median values of the analyzed parameters (biochemical parameters and specific bioindicators) of 48 patients treated with piroxicam, ketoprofen, ibuprofen and celecoxib are shown in Tables 2 and 3.

From the results presented in Table 2 and 3 it is observed that patients treated long-term with piroxicam, ketoprofen, ibuprofen and celecoxib, who had shown migraine episodes lasting less than 15 days per month, had significantly different serum urea (BUN), sodium in serum, microalbuminuria and $\beta 2 \mathrm{M}$ levels. Significant difference was observed for patients treated with piroxicam, ketoprofen, ibuprofen and celecoxib with respect to serum urea concentrations at $\mathrm{p}=0.0001$. This overall significance was due to significantly higher urea values in the group treated with ketoprofen compared to the group treated with ibuprofen (median 5.55 vs 4.15, $\mathrm{p}=0.045$ ), and significantly higher values in the group treated with celecoxib compared to the treated group of piroxicam and ibuprofen (median 6.4 vs $4.4, p=0.003 ; 6.4$ vs $4.15, \mathrm{p}=0.0004)$. 
Table 3. Comparison of the mean and median values of the analyzed parameters (KS, ClS, MA and $\beta 2 \mathrm{M})$ of Piroxicam, Ketoprofen, Ibuprofen and Celecoxib.

\begin{tabular}{|c|c|c|c|c|c|c|}
\hline \multirow{3}{*}{$\begin{array}{l}\text { Biochemical } \\
\text { Parameters }\end{array}$} & \multirow{3}{*}{$\begin{array}{c}\text { median } \\
(25-75 \text { percentiles })\end{array}$} & \multicolumn{5}{|c|}{ p-level } \\
\hline & & \multirow[b]{2}{*}{ Group 2/3/8/9 } & \multicolumn{4}{|c|}{ Groups } \\
\hline & & & & Ketoprofen & Ibuprofen & Celecoxib \\
\hline \multirow[t]{4}{*}{ KS } & $4.4(4.1-4.55)$ & $\mathrm{H}=3.59$ & Piroxicam & & & \\
\hline & $4.55(4.15-5.1)$ & $\mathrm{p}=0.3100 \mathrm{~ns}$ & Ketoprofen & & & \\
\hline & $4.2(4.2-4.65)$ & & Ibuprofen & & & \\
\hline & $4.2(4.2-4.35)$ & & Celecoxib & & & \\
\hline \multirow[t]{4}{*}{$\mathrm{ClS}$} & $100.5(98.5-101.5)$ & $\mathrm{H}=3.41$ & Piroxicam & & & \\
\hline & $99(98-100)$ & $\mathrm{p}=0.3300 \mathrm{~ns}$ & Ketoprofen & & & \\
\hline & $97.5(97-100.5)$ & & Ibuprofen & & & \\
\hline & $99(99-100)$ & & Celecoxib & & & \\
\hline \multirow[t]{4}{*}{ MA } & $20(10-30)$ & $\mathrm{H}=10.12$ & Piroxicam & $\mathrm{ns}$ & ns & ns \\
\hline & $30(20-30)$ & $\mathrm{p}=0.0170 \mathrm{sig}$ & Ketoprofen & & ns & $0.0480 \mathrm{sig}$ \\
\hline & $10(10-30)$ & & Ibuprofen & & & ns \\
\hline & $10(10-10)$ & & Celecoxib & & & \\
\hline \multirow[t]{4}{*}{$\beta 2 \mathrm{M}$} & $0.206(0.206-0.209)$ & $\mathrm{H}=18.53$ & Piroxicam & $\mathrm{ns}$ & ns & $0.0130 \mathrm{sig}$ \\
\hline & $0.206(0.206-0.213)$ & $\mathrm{p}=0.0003 \mathrm{~ns}$ & Ketoprofen & & ns & $0.0030 \mathrm{sig}$ \\
\hline & $0.206(0.203-0.206)$ & & Ibuprofen & & & $\mathrm{ns}$ \\
\hline & $0.201(0.186-0.206)$ & & Celecoxib & & & \\
\hline
\end{tabular}

${ }^{*} H$ (Kruskal-Wallis test)

* post - hoc (Mann-Whitney test)

$C l S$-chlorides in serum, $M A$ - microalbuminuria, $\beta 2 M$ - $\beta 2$ microglobulin.

Post-hoc analysis of the inter-group differences between piroxicam, ketoprofen, ibuprofen and celecoxib comparing to the serum sodium concentrations showed that this overall significance was due to a significantly higher serum sodium level in patients treated with piroxicam compared to patients receiving celecoxib (median 140 vs 137, $\mathrm{p}=0.033$ ). The results were of great clinical relevance because they indicate that NSAIDs, as cyclooxygenase inhibitors (non-selective COX-1 inhibitor and selective COX-2 inhibitor) influence the increase in degradation products (serum urea, creatinine in serum and urine) as well as changes in tubular electrolyte reabsorption. The results correspond to those of Kim and Clive (2007) and their associates who followed patients with an increased predisposition to nephrotoxicity when treated with non-selective NSAID and selective COX-2 inhibitors - celecoxib. Both groups showed changes in electrolyte status, with marked hyponatraemia and hyperkalemia. On the other hand, Hegazy et al. (2011) following serum creatinine, clearance creatinine, and serum electrolytes, concluded that patients treated with ibuprofen had significantly higher serum creatinine values compared to patients treated with celecoxib. In both patient groups, insignificant changes in serum electrolyte levels were observed.

In fact, while until recently elevated serum creatinine was largely considered the "gold standard" for detecting AKI. Nowadays, it is clear that serum creatinine changes when $50 \%$ of renal function is lost. According the results of the study conducted by Mahrukh et al. (2017), the blood urea (BUN) levels can be falsely elevated in subjects with protein diet, tissue disorders, gastrointestinal bleeding, total parenteral nutrition and dehydrated individuals.

It is therefore very important, in addition to these parameters, to follow specific biomarkers for early identification of renal impairment such as low molecular protein (microalbuminuria and $\beta 2 \mathrm{M}$ ).

Urinary albumin excretion was significantly different in the groups treated with piroxicam, ketoprofen, ibuprofen, and celecoxib ( $\mathrm{p}=0.017)$. Intergroup trials and comparisons have shown that treatment with ketoprofen significantly increases microalbuminuria (marker for early detection of glomerular damage) compared to treatment with celecoxib (median $30 \mathrm{vs} 10, \mathrm{p}=0.048$ ). At $\mathrm{p}=0.0003$, a significant overall difference between the four groups of patients and $\beta 2 \mathrm{M}$ (markers for early detection of proximal tubular damage) values was confirmed. Values of this parameter were significantly lower in patients treated with celecoxib compared to patients treated with piroxicam $(\mathrm{p}=0.013)$ and ketoprofen $(\mathrm{p}=0.003)$. Mean $\beta 2 \mathrm{M}$ values in patients treated with piroxicam, ketoprofen, ibuprofen and celecoxib were 0.206 vs 0.201 . The results are of great clinical relevance because they indicate that in patients with cephaleamigraines, changes in glomeruli and proximal tubules have been identified, whereas in patients with celecoxib they have been found to be significantly lower in values or smaller changes in renal function, is believed to be due to shorter treatment time for patients with Celecoxib 200 
mg over a 12-month period compared to other NSAID groups treated over a longer period of 5 to 10 years, the sensitivity of biomarkers is also confirmed. These results correspond with the claims of Pedersen et al. (1995), that biomarker microalbuminuria is a more sensitive indicator for the identification of renal dysfunction and should be used as a useful tool for the management of non-clinical patients. According to Swan et al. (2000), relatively selective COX-2 inhibitors are more renoprotective than COX-1 inhibitors, consequently, there is evidence of a higher incidence of acute kidney injury (AKI) in patients treated with COX-1 inhibitors (indomethacin, ibuprofen and piroxicam) (Griffin et a.1, 2003; Silverstein et al., 2000). To confirm the sensitivity of specific biomarkers the comparison of piroxicam, ketoprofen, ibuprofen and celecoxib with respect to the analyzed parameters are presented in Table 4.

Table 4 is showing the distribution of the frequency of increased or reduced values of the parameters analyzed in groups piroxicam, ketoprofen, ibuprofen and celecoxib. The results show that the greatest deviations were observed in $\beta 2 \mathrm{M}$ in terms of its increase in all patients treated with piroxicam and ketoprofen, in $91.7 \%$ of the patients treated with ibuprofen, and in $50 \%$ of the patients treated with celecoxib. Tested difference of the distribution of patients with normal values and deviations from the reference values among the three drug groups was statistically significant for chlorides $(p=0.016)$, microalbuminuria $(p=0.029)$ and $\beta 2 \mathrm{M}(\mathrm{p}=0.002)$. The most frequent decrease was in creatinine values in the urine, i.e. $50 \%$ of patients in the group treated with piroxicam, $66.7 \%$ of the group treated with ketoprofen and ibuprofen, and $75 \%$ of patients treated with celecoxib had decreased creatinine in the urine, which from a clinical biochemical point of view have no clinical significance.

Based on the data obtained for microalbuminuria and $\beta 2 \mathrm{M}$ in patients with chronic headache-migraine, the identified changes in the tubules. From a biochemical point of view, this suggests that cyclooxygenase inhibitors have a significant effect on changes in epithelial cels of proximal tubules which is directly related to the increase in urinary excretion of low molecular protein $\beta 2 \mathrm{M}$ (as early marker for identifieating tubular disfunctionin) and catabolism in the proximal tubules. Based on monitoring of microalbuminuria (as a marker for early identification of renal impairment at the glomerular level), changes in glomeruli have been detected, which once again confirm the sensitivity of specific biomarkers.

On the basis of monitoring the frequency distribution of increased or decreased values of the analyzed parameters according to the nephrological protocol serum urea (BUN), serum creatinine $(\mathrm{CrS})$, urinary creatinine $(\mathrm{CrU})$ in the groups, an increase was observed only in the values of urea serum (BUN) but it does not have particular clinical importance since (Mahrukh et al., 2017).

Table 4. Comparison-Piroxicam, Ketoprofen, Ibuprofen and Celecoxib, with respect to the parameters analyzed (normal values and values deviating from the reference).

\begin{tabular}{|c|c|c|c|c|c|c|c|c|}
\hline \multirow[b]{2}{*}{$\begin{array}{l}\text { Biochemical } \\
\text { parameters }\end{array}$} & \multirow[b]{2}{*}{ Ref. value } & \multirow[b]{2}{*}{ Unites } & \multirow[b]{2}{*}{ Values } & \multicolumn{5}{|c|}{ Group } \\
\hline & & & & $\mathrm{N}$ & $\begin{array}{c}\text { Piroxicam } \\
\mathrm{N}=12\end{array}$ & $\begin{array}{c}\text { Ketoprofen } \\
\mathrm{N}=12\end{array}$ & $\begin{array}{c}\text { Ibuprofen } \\
\mathrm{N}=12\end{array}$ & $\begin{array}{c}\text { Celecoxib } \\
\mathrm{N}=12\end{array}$ \\
\hline $\begin{array}{l}\text { BUN } \\
\text { p-level }\end{array}$ & $2.5-6.4$ & $\mathrm{mmol} / \mathrm{L}$ & $\begin{array}{l}\text { Increased } \\
{ }^{\mathrm{b}} 0.097 \mathrm{~ns}\end{array}$ & 10 & $2(16.67)$ & $3(25)$ & 0 & $5(41.67)$ \\
\hline $\begin{array}{l}\mathrm{CrS} \\
\text { p-level }\end{array}$ & $49-90$ & $\mu \mathrm{mol} / \mathrm{L}$ & $\begin{array}{l}\text { Reduced } \\
\text { b0.173 ns }\end{array}$ & 4 & 0 & $3(25)$ & 0 & $1(8.33)$ \\
\hline $\begin{array}{l}\text { CrU } \\
\text { p-level }\end{array}$ & $13.3-22.1$ & $\mathrm{mmol} / \mathrm{L}$ & $\begin{array}{l}\text { Reduced } \\
{ }^{\mathrm{b}} 0.716 \mathrm{~ns}\end{array}$ & 31 & $6(50)$ & 8 (66.67) & $8(66.67)$ & $9(75)$ \\
\hline $\mathrm{NaS}$ & $136-143$ & $\mathrm{mmol} / \mathrm{L}$ & Reduced & 2 & 0 & 0 & $1(8.33)$ & $1(8.33)$ \\
\hline $\begin{array}{l}\text { ClS } \\
\text { p-level }\end{array}$ & $3.5-5.1$ & $\mathrm{mmol} / \mathrm{L}$ & $\begin{array}{l}\text { Reduced } \\
{ }^{\mathrm{b}} 0.016 \mathrm{sig}\end{array}$ & 9 & $2(16.67)$ & 0 & $6(50)$ & $1(8.33)$ \\
\hline $\begin{array}{l}\text { MA } \\
\text { p-level }\end{array}$ & $<20$ & $\mathrm{mg} / \mathrm{L}$ & $\begin{array}{l}\text { Increased } \\
{ }^{\mathrm{a}} 0.029 \mathrm{~ns}\end{array}$ & 21 & $6(50)$ & $9(75)$ & $4(33.33)$ & $2(16.67)$ \\
\hline $\begin{array}{l}\beta 2 \mathrm{M} \\
\text { p-level }\end{array}$ & $<0.2$ & $\mathrm{mg} / \mathrm{L}$ & $\begin{array}{l}\text { Increased } \\
{ }^{b} 0.002 \text { sig }\end{array}$ & 41 & $12(100)$ & $12(100)$ & 11 (91.67) & $6(50)$ \\
\hline
\end{tabular}




\section{Conclusion}

Sensitivity of specific bioindicators to detect early stage nephrotoxicity at glomerular level microalbuminuria, as well as at tubular level - and $\beta 2 \mathrm{M}$ has been demonstrated in the treatment of patients with cephalea with non-selective COX inhibitors (piroxicam, ketoprofen and ibuprofen) and selective COX-2 inhibitors (celecoxib). Based on the results, we confirm the renoprotection of celecoxib. Individualized and rational use of NSAIDs is recommended, due to the danger of increasing the potential for nephrotoxicity over the duration of therapy as well as constant monitoring of renal function in patients.

\section{References}

Barasch, J., Cincinnati Children's Hospital Medical Center and Columbia University of New York, 2005. Method for the early detection of renal injury. U.S. Patent Application 11/096, 113. Available at: https://patents.google.com/patent/US20100028919.

Clive, D.M., Stoff, J.S., 1984. Renal syndromes associated with nonsteroidal antiinflammatory drugs. New England Journal of Medicine 310(9), 563-572. Available at: https://doi.org/10.1056/NEJM198403013100905.

Davis, M.E., Berndt, W.O., 1994. Renal methods for tocicology. Principles and methods of toxicology, third ed. Raven Press Ltd, New York, pp. 871-894.

Derry, S., Rabbie, R., Moore, R.A., 2013. Diclofenac with or without an antiemetic for acute migraine headaches in adults. Cochrane Database of Systematic Reviews (4). Available at: https://www.cochrane.org/CD008783/SYMPT_diclofenacor-without-antiemetic-acute-migraine-headaches-adults.

Ejaz, P., Bhojani, K., Joshi, V.R., 2004. NSAIDs and kidney. JAPI 52(632-640), 371. Available at: https://www.ncbi.nlm.nih.gov/pubmed/15847359.

Evers, S., Afra, J., Frese, A., Goadsby, P.J., Linde, M., May, A., Sándor, P.S., 2009. EFNS guideline on the drug treatment of migraine-revised report of an EFNS task force. European Journal of Neurology 16(9), 968-981. Available at: https://doi.org/10.1111/j.1468-1331.2009.02748.x.

Furst, D.E., 1997. Meloxicam: selective COX-2 inhibition in clinical practice. Seminars in Arthritis and Rheumatism 26(Suppl 1), 21-27. Available at: https://doi.org/10.1016/s0049-0172(97)80049-2.

Giffin, N.J., Ruggiero, L., Lipton, R.B., Silberstein, S.D., Tvedskov, J.F., Olesen, J., Altman, J., Goadsby, P.J., Macrae, A., 2003. Premonitory symptoms in migraine: an electronic diary study. Neurology 60(6), 935-940. Available at: https://doi.org/10.1212/01.wnl.0000052998.58526.a9.

Harris, R.C., Breyer, M.D., 2006. Update on cyclooxygenase-2 inhibitors. Clinical Journal of the American Society of Nephrology 1(2), 236-245. Available at: https://doi.org/10.2215/CJN.00890805.

Hegazy, R., Alashhab, M., Amin, M., 2011. Cardiorenal effects of newer NSAIDs (Celecoxib) versus classic NSAIDs (Ibuprofen) in patients with arthritis. Journal of Toxicology 2018. Available at: https://doi.org/10.1155/2011/862153.
John, F., Rothrock, M.D., 2011. Available at: https://americanmigrainefoundation.org/resourcelibrary/acute-migraine-treating-early/.

Kim, S., Joo, K.W., 2007. Electrolyte and Acid-base disturbances associated with non-steroidal antiinflammatory drugs. Electrolyte \& Blood Pressure 5(2), 116-125. Available at: https://doi.org/10.5049/EBP.2007.5.2.116.

Liangos, O., Perianayagam, M.C., Vaidya, V.S., Han, W.K., Wald, R., Tighiouart, H., MacKinnon, R.W., Li, L., Balakrishnan, V.S., Pereira, B.J., Bonventre, J.V., 2007. Urinary $\mathrm{N}$-acetyl- $\beta$-(D)-glucosaminidase activity and kidney injury molecule-1 level are associated with adverse outcomes in acute renal failure. Journal of the American Society of Nephrology 18(3), 904-912. Available at: https://doi.org/10.1681/ASN.2006030221.

Lipton, R.B., Stewart, W.F., Diamond, S., Diamond, M.L., Reed, M., 2001. Prevalence and burden of migraine in the United States: data from the American Migraine Study. Headache 41(7), 646-57. Available at: https://doi.org/10.1046/j.1526-4610.2001.041007646.x.

Munjal, S., Bennett, A., 2017. Efficacy and safety of DFN-15, an oral liquid formulation of celecoxib, in adults with migraine: a multicenter, randomized, placebo-controlled, double-blind, crossover study. Neuropsychiatric Disease and Treatment 13, 2797. Available at: https://doi.org/10.2147/NDT.S151834.

Parezela, M.A., Tras, K., 2001. Selective cyclooxygenase-2 inhibitors: a pattern of nefrotoxicity similar to traditional nonsteroidal anti-inflammatory drugs. Am. J. Med. 111, 6467. Available at: https://doi.org/10.1016/S0002-9343(01)00757-4.

Pedersen, L.M., Nordin, H., Svensson, B., Bliddal, H., 1995. Microalbuminuria in patients with rheumatoid arthritis. Annals of the Rheumatic Diseases, 54(3), 189192. Available at : http://dx.doi.org/10.1136/ard.54.3.189.

Quiralte, J., Blanco, C., Delgado, J., Ortega, N., Alcántara, M., Castillo, R., Anguita, J.L., de San Pedro, B.S., Carrillo, T., 2007. Challenge-based clinical patterns of 223 Spanish patients with nonsteroidal anti-inflammatory-drug-induced reactions. Journal of Investigational Allergology and Clinical Immunology 17(3), 182. Available at: https://www.ncbi.nlm.nih.gov/pubmed/17583106.

Raz, A., 2002. Is inhibition of cyclooxygenase required for the anti-tumorigenic effects of nonsteroidal, anti-inflammatory drugs (NSAIDs)?: in vitro versus in vivo results and the relevance for the prevention and treatment of cancer. Biochemical Pharmacology 63(3), 343-347. Available at: https://doi.org/10.1016/S0006-2952(01)00857-7.

Rizvi, M.S., Kashani, K.B., 2017. Biomarkers for early detection of acute kidney injury. JALM 2(3), 386 -399. Available at: https://doi.org/10.1373/jalm.2017.023325.

Rozen, T.D., Swanson, J.W., Stang, P.E., McDonnell, S.K., Rocca, W.A., 1999. Increasing incidence of medically recognized migraine headache in a United States population. Neurology 53(7). 1468-1468. Available at: https://doi.org/10.1212/wnl.53.7.1468.

Schneider, V., Lévesque, L.E., Zhang, B., Hutchinson, T. and Brophy, J.M., 2006. Association of selective and conventional nonsteroidal antiinflammatory drugs with acute renal failure: a population-based, nested case-control analysis. American Journal of Epidemiology 164(9), 881889. Available at: https://doi.org/10.1093/aje/kwj331.

Макед. фарм. билт., 66 (1) 55 - 63 (2020) 
Silverstein, F.E., Faich, G., Goldstein, J.L., Simon, L.S., Pincus, T., Whelton, A., Makuch, R., Eisen, G., Agrawal, N.M., Stenson, W.F., Burr, A.M., 2000. Gastrointestinal toxicity with celecoxib vs nonsteroidal anti-inflammatory drugs for osteoarthritis and rheumatoid arthritis: the CLASS study: a randomized controlled trial. JAMA 284(10), 1247-1255. Available at: https://doi.org/10.1001/jama.284.10.1247.

Spasovski, D., Gruev, T., Marina, Calovski, J., Percinkova, S., Osmani, B., Rajčevska, Lj., Cakalaroski, K., Sotirova, T., Balkanov, S., Slaninka-Micevska, M., 2007. The diagnoistic value of $\mathrm{N}$ - acetyl $\beta$-glucosaminidase and microalbumin concentrations in rheumatoid arthritis. JMB 26, 300-308. Available at: https://doi.org/10.2478/v10011-007-0038-0.

Stewart, W.F., Lipton, R.B., Celentano, D.D., Reed, M.L., 1992. Prevalence of migraine headache in the United States: relation to age, income, race, and other sociodemographic factors. JAMA 267(1), 64-69. Available at: https://doi.org/10.1001/jama.1992.03480010072027.

Suleyman, H., Demircan, B., Karagoz, Y., 2007. Antiinflammatory and side effects of cyclo-oxygenase inhibitors. Pharmacological Reports 59(3), 247. Available at: https://www.ncbi.nlm.nih.gov/pubmed/17652824

Swan, S.K., Rudy, D.W., Lasseter, K.C., Ryan, C.F., Buechel, K.L., Lambrecht, L.J., Pinto, M.B., Dilzer, S.C., Obrda, O., Sundblad, K.J., Gumbs, C.P., Ebel, D.L., Quan, H., Larson, P.J., Schwartz, J.I., Musliner, T.A., Gertz, B.J., Brater, D.C., Yao, S.L., 2000. Effect of cyclooxygenase-2 inhibition on renal function in elderly persons receiving a low-salt diet. A randomized, controlled trial. Ann. Intern. Med. 133, 1-9. Available at: https://doi.org/10.7326/00034819-133-1-200007040-00002.

Swan, G., Naidoo, V., Cuthbert, R., Green, R.E., Pain, D.J., Swarup, D., Prakash, V., Taggart, M., Bekker, L., Das, D., Diekmann, J., 2006. Removing the threat of diclofenac to critically endangered Asian vultures. PLoS Biology 4(3), e66. Available at: https://doi.org/10.1371/journal.pbio.0040066.
Tulunay, F.C., 2000. NSAIDs: behind the mechanisms of action. Functional neurology 15 (Suppl 3), 202-207. Available at: http://europepmc.org/article/MED/11200793.

Weir, M.R., 2002. Renal effects of nonselective NSAIDs and coxibs. Cleveland Clinic Journal of Medicine 69(Suppl 1), 53-58. Available at: https://doi.org/10.3949/ccjm.69.Suppl_1.SI53.

Whelton, A., Maurath, C.J., Verburg, K.M. and Geis, G.S., 2000. Renal safety and tolerability of celecoxib, a novel cyclooxygenase-2 inhibitor. American Journal of Therapeutics 7(3), 159-175. Available at: https://jhu.pure.elsevier.com/en/publications/renal-safetyand-tolerability-of-celecoxib-a-novel-cyclooxygenase-3.

Winkelmayer, W.C., Waikar, S.S., Mogun, H., Solomon, D.H., 2008. Nonselective and cyclooxygenase-2-selective NSAIDs and acute kidney injury. The American Journal of Medicine 121(12), 1092-1098 Available at: https://doi.org/10.1016/j.amjmed.2008.06.035.

Yzeri Havziu, D., Hiljadnikova-Bajro, M., Kadifkova Panovska, T., Bexheti, N., 2016. Renal function of patients with rheumatoid arthritis treated with piroxicam. Acta Medica Balkanica - International Journal of Medical Sciences 1(2), 1-13.

Yzeiri Havziu, 2014. Nephrotoxicity of nonsteroidal antiinflammatory drugs. Faculty of Pharmacy, Ss. Cyril and Methodius University in Skopje.

Yzeiri Havziu, D., Gjorgjeska, B., Cvetkovska, D., Bilali, S., Nikolov, I., 2019. Early detection of nephrotoxicity in patients with Medication-overuse headache (MOH). Acta Medica Balkanica - International Journal of Medical Science 4(7-8), 13-22. Available at: https://journals.indexcopernicus.com/search/journal/issue? issueId=201620\&journalId $=51219$.

Yzeiri Havziu, D., Hiljadnikova-Bajro, M., Kadifkova Panovska, T., Gjorgjeska, B., 2018. Nephrotoxicity of NSAIDs and MTX. Acta Medica Balcanica 3(5), 13-18. Available at: http://eprints.unite.edu.mk/id/eprint/62. 


\title{
Споредба на негативни бубрежни ефекти на различни видови на НСАИЛ врз основа на инхибиција на СОХ кај пациенти со главоболки
}

\author{
Дрита Узеири Хавзиу ${ }^{1}$, Билјана Ѓорѓеска², Висар Мифтари ${ }^{3}$, \\ Едита Алили Идризи ${ }^{1}$, Гуллај Алија ${ }^{1}$, Арлинда Хаџиу Заими ${ }^{1}$ \\ ${ }^{I}$ Факултет за медицински науки, Државен универзитет во Тетово, \\ ул. Илинден бб 1200, 1220 Тетово, Република Северна Македонија \\ ${ }^{2}$ Медицински факултет, Универзитет „Гоце Делчев”, ул. Крсте Мисирков, \\ 2000 Штип, Република Северна Македонија \\ ${ }^{3}$ Клиника за неврологија, Клиничка болница, ул. 29 Ноември, 1220 Тетово, \\ Република Северна Македонија
}

Клучни зборови: несакани бубрежни ефекти, нестероидни антиинфламаторни лекови, мигрена

Мигрената претставува вообичаена главоболка, која предизвикува значајни пореметувања. Неселективните инхибитори на циклооксигеназата (COX): пироксикам, кетопрофен и ибупрофен се најчесто препишуваните нестероиди антиинфламаторни лекови (НСАИЛ) наменети за третман на главоболка. Целекоксиб е уште еден НСАИЛ којшто е одобрен во последните неколку години, кој се карактеризира со различни механизми на делување. Целта на оваа студија е да се следи реналната функција и да се споредат нефротоксичните делувања на различните видови НСАИЛ чие што дејство се заснова на инхибиција на СОХ, кај пациетни со цефалеа-мигрена кои што се третирани подолг период.

Покрај конвенционалните маркери на реналната функција (креатинин во серум/урина, определен според Јaffeовата метода и уреа во серум, определена со ензимска метода), со цел мониторирање на гломеруларните и тубуларните функции, користевме нефелометрија за определување на $\beta 2$ Microglobulin ( $\beta 2 \mathrm{M})$ и фотоелектрична колоримтерија за определување на микроалбуминуријата во урината. Било каква историја на заболување на бубрезите беше критериум за исклучување на пациентите од оваа студија.

Резултатите покажуваат дека постои голем пораст на нивоата на $\beta 2 \mathrm{M}$ кај сите пациенти кои беа под терапија со пироксикам и кетопрофен, кај $91,7 \%$ од пациентите под терапија со ибупрофен, и кај $50 \%$ од пациентите под терапија со целекоксиб. Најчестото зголемување беше забележано кај вредностите на креатининот во урината, кај $50 \%$ од пацентите третирани со пироксикам, 66,7 \% од пациентите третирани со кетопрофен и ибупрофен, и $75 \%$ од пациентите третирани со целекоксиб.

Врз основа на добиените резултати за нивоата на специфичните биомаркери во урината, ние препорачуваме постојано следење на реналните фунции при користење на различни групи НСАИЛ и внимателност при користење аналгетици и антиинфламаторни лекови. 
